\title{
Trend and Novel Possibilities of Dairy Wastewater Treatment by Membrane Filtration
}

\author{
Elias Jigar Sisay ${ }^{1,2}$ and Zsuzsanna László ${ }^{2, *}$ \\ ${ }^{1}$ Doctoral School of Environmental Sciences, University of Szeged, Hungary. H-6720, Rerrich B. tér 1. \\ ${ }^{2}$ Department of Biosystem Engineering, Faculty of Engineering, University of Szeged, H-6725 Szeged, Moszkvai krt. 9.
}

Received 7 January 2021; Accepted 3 March 2021

\begin{abstract}
Membrane separation processes for wastewater treatment in dairy industry gives so many benefits such as less ecological footprint, reliable contaminant removal, low cost, possibility of renewable energy use, simple technology and can easily integrate with other processes. However, the fouling issue limits its widespread application. Self-cleaning membrane technology, through membrane modification by heterogeneous photo-catalytic nanomaterials and their composites, has been given more attention by many researchers. In this paper, characteristics of dairy wastewater and possible membrane separation processes applications in dairy wastewater treatment are summarised and discussed. Fouling mechanisms of protein, the interaction of molecules, factors affecting fouling are highlighted. Physical, chemical, and self-cleaning fouling control and mitigation strategies are reviewed. Membrane modifications by renewable or non-renewable energy-driven heterogeneous photo-catalysis and possible ways that enhance the photocatalytic efficiency are also addressed. Finally, challenges and prospective solutions are reviewed.
\end{abstract}

Keywords: Dairy wastewater, membrane separation processes, fouling, heterogeneous photo-catalysis, renewable energy, selfcleaning membrane

\section{Introduction}

Protection of water resource is unquestionably among the most critical problems in the world. According to Mancosu et al [1], food production uses over $3 / 5$ of the freshwater consumption of the world; among them dairy industry alone generates $9 \%$ of food industrial wastewaters [2]. Dairy industry of many countries generates huge volume and pollution load of wastewater [3]. The effluent is primarily made up of carbohydrates, proteins and fats and remaining cleaning agents. It contains high load of organic matter and nutrients (e.g., nitrogen and phosphorous) [4]. Discharging that kind of wastewater affects all types of ecosystems and result in severe environmental harms, for instance eutrophication due to high nutrient content of the wastewater [5]. Such problems brought an alarm that the dairy wastewater needs to be addressed before its release to the environment, for example, the high chemical oxygen demand (COD) value need to be decreased to acceptable level [6].

In most countries, the dairy wastewaters are treated with traditional techniques, aiming the minimal necessary reduction of COD or biological oxygen demand (BOD) to turn the wastewater handable together with municipal wastewaters. During the treatment, the valuable nutrients in the stream are converted into less harmful form: e.g., ammonia to nitrogen, phosphate is precipitated. In spite of their value, they are hardly used as nutrients or fertilizers; on the other hand, the modern industry uses huge amount of energy and non-renewable sources for fertilizer production:

*E-mail address: zsizsu@mk.u-szeged.hu

ISSN: 1791-2377 @ 2021 School of Science, IHU. All rights reserved. doi:10.25103/jestr.141.04 energy, mineral P-sources or coal to generate hydrogen for ammonia synthesis [7]. Besides the evidence of necessity of the water reuse, the recovery of nutrients as $\mathrm{N}$ and $\mathrm{P}$ is rarely taken into consideration; however, the return of nutrients to agriculture may close the cycle [8].

By now, several methods were developed and applied for water reclamation and reuse [9], however, they had risks, e.g., wastewaters may contain potentially harmful pathogens, nanoparticles, disinfection by-products or cleaning agents and detergents. There are several newly developed methods to eliminate these problems, e.g., AOP's (advanced oxidation processes) became good alternatives to disinfection by chlorination [8]. Besides them, membrane technology also represents a good alternative to treat these waters.

In terms of nutrient recovery, several techniques are available, both physical, chemical, and biological processes. However, basic requirement for all these processes to separate the nutrients from other pollutants of wastewater. Nowadays, the most widely used $\mathrm{N}$ and $\mathrm{P}$ recovery method is the struvite formation by crystallization and precipitation [10]. As there are several difficulties linked to this process, applying membrane separation, which enable to concentrate or separate the nutrients may be advantageous.

Membrane technology is more energy-efficient, environmentally friendly, and low cost as compared with the conventional methods [11]. But these processes suffer from fouling. The fouling because of the hydrophobicity of the membrane decreases flux and increases energy use which hinder the wider application of the technology [12].

Previous dairy wastewater treatment studies mainly focused on physicochemical and biological methods [13] and membrane separation applications [14][15][16][17]. In recent years, the application of membrane separation for dairy 
wastewater treatment is growing, as several novel and emerging techniques have studied and developed to overcome the limitations of membrane separation processes. Recent publications have focused on fouling reduction by offering innovative cleaning processes, optimizing the existing techniques, or integrating devices to the membrane set-up.

In this paper, we provide a review of up-to-date literature and of the recent developments of membrane separation processes in dairy wastewater treatment. The review also provides current strategies used to control and to prevent fouling in the membrane separation processes. A summary of factors affecting fouling are also addressed. Finally, our paper summarizes the treatment possibilities which meet the requirements of circular economy and reveal the problems to be solved in the near future for making membrane technology good and environmentally friendly alternative in dairy wastewater treatment.

\section{Membrane filtration in dairy industry}

Dairy industries produce several kinds of milk products (fluid milk, butter, cheese, yoghurt and so on) and by-products (dairy wastewater) [18].

Membrane filtration widely have been used in dairy industry for decades, mainly for protein recovery via ultrafiltration [19]. Caseins and whey proteins are the two kinds of milk proteins mainly found in skim milk and whey, respectively. Caseins are the primary group of milk proteins with small size micelles joined together by calcium phosphate bridges to form large size micelles in milk [20]. Caseins are classified as $\beta$-casein, $\kappa$-casein, $\alpha$ s-casein, and $\alpha$ s-casein and are the highest, moderate and lowest hydrophobic respectively [21]. The remaining milk proteins in the whey after cheese making is whey proteins. Bovine serum albumin (BSA), $\alpha$-lactalbumin ( $\alpha$-LA), and $\beta$-lactoglobulin ( $\beta$-LG) are whey proteins [22].

Beside the protein recovery, membrane technology is used for clarification of milk, separation of milk components by size or concentration of valuable components, moreover, it may provide environmentally friendly and economical alternatives to several unit operations of milk processing, such as centrifugation, whey demineralization or evaporation [23].

\section{Characterization of Industrial Dairy Wastewater}

The dairy wastewaters characteristics differ by technologies and factories. Processes in dairy industries involve multiple sections processing, cooling, heating processes cleaning (soda, nitric- and phosphoric acid or sodium hypochlorite) and washing [24][25]. Each of the various units in the process generates wastewater [4][25], and its characteristics strongly depends on the products, the operational circumstances, and the applied wastewater treatment process too. The chemical compositions may vary in a wide range, and generally it is characterized by COD (chemical oxygen demand), BOD (biological oxygen demand), $\mathrm{pH}$, TSS (total suspended solids), TS (total solid), $\mathrm{NH}_{3}$ (Ammonia), and $\mathrm{PO}_{4}{ }^{3-}$ (Phosphate) as reported by authors are given in Table 1

\subsection{Membrane fouling and mechanisms}

Membrane separation process applications continue to increase, but these processes challenged by fouling that affect permeate flux with parallel increasing energy consumption [12]. Membrane fouling is the unwanted deposition of solutes inside or outside parts of the membrane [36]. Various characteristics could be considered in to account to classify fouling. First, depending on foulant composition (biofouling, organic fouling, and inorganic fouling). Second, based on fouling reversibility (reversible and irreversible), and third, based on fouling location (concentration polarization, internal fouling, and external fouling). It is important to study the fouling mechanisms of each foulants. The fouling mechanisms can be through concentration polarization, adsorption, cake, gel, scaling, pore blocking, and biofilm [37].

Membrane fouling reduces separation efficiency of membranes, increase of maintenance and operation costs. As a result of its effect, fouling is nowadays becoming the main obstacles for development of membrane technologies [38].

\section{Protein fouling}

The protein content of the dairy wastewater was found to be severe foulant for polymeric membrane materials [6]. The study by $\mathrm{Ng}$ et.al., [22] have provided significant insight into fouling components and mechanisms of fouling are illustrated in Figure. 1.

As illustrated in Fig. 1., whey proteins (WPs) are smaller in size than casein micelles (CMs). The size variations between them bring about composition differences in the concentration polarization (CP) layer [22].

Generally, proteins, emulsified oils, microorganisms, and humic materials have a higher fouling propensity to hydrophobic membranes than hydrophilic membranes [12]. Therefore, many surface modifications deal to change hydrophobic membrane surface into hydrophilic. Because hydrophilic surfaces tend to bind a layer of water, which discourage the accumulation of foulants from the solution [39].

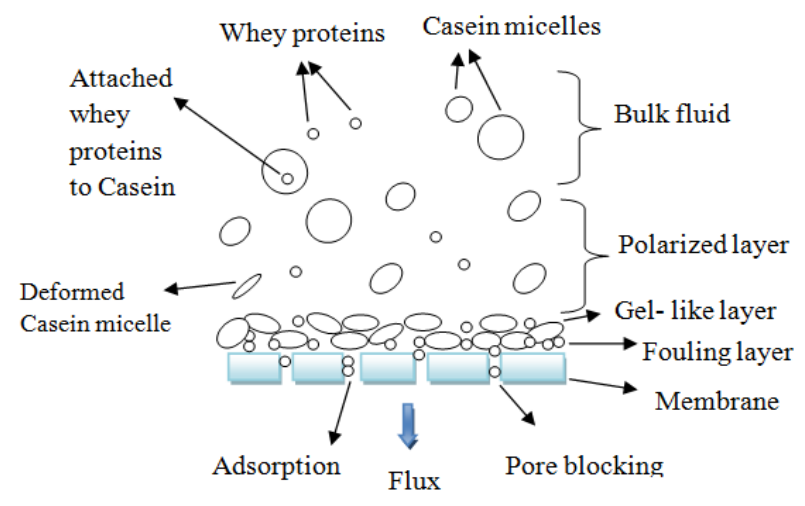

Fig. 1. Graphical representation of fouling process during skim milk UF (modified from [22]).

\subsection{Factors affecting membrane fouling}

There are three factors influencing fouling, these are membrane properties, feed water composition and hydrodynamic (also known as operating) parameters [40], as shown in Fig. 2.

\section{Interactions between the membrane and dairy wastewater components}

Surface hydrophilicity, surface charge, and surface smoothness are important membrane surface properties that affect membrane fouling [41]. Hydrophilic, smooth, and low surface charge membranes have shown a better fouling resistance at the beginning phase of fouling. But severe fouling obtained at later phase of fouling due to foulant-to- 
foulant interactions. Repulsive charges between membrane and foulant may reduce fouling by repelling [42]. The resultant attraction or repulsion forces are mainly influenced by hydrophobicity and the charge of the membrane which finally affect the degree of fouling [43]. More benefits can be obtained in terms of protein-membrane interaction by manipulating hydrophobicity and their charge, which is minimal at their isoelectric point. Their hydrophobic interactions and aggregation lead to their deposition and fouling [44]. The membrane-solute interactions are summarized in Fig.3.

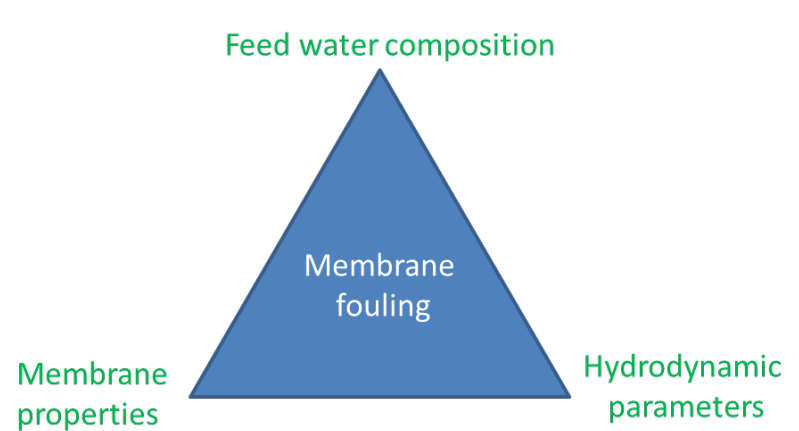

Fig. 2: Factors affecting membrane fouling

Table 1. Characteristics of dairy wastewaters

\begin{tabular}{|c|c|c|c|c|c|c|c|c|}
\hline \multirow[t]{2}{*}{ Waste type } & \multicolumn{7}{|c|}{ Constituent in mg/L except pH } & \multirow[t]{2}{*}{ References } \\
\hline & COD & BOD & pH & TSS & TS & $\mathbf{N H}_{3}$ & $\mathrm{PO}_{4}{ }^{3-}$ & \\
\hline Dairy effluent & $\begin{array}{l}190 \\
2700\end{array}$ & $\begin{array}{l}120 \\
1800\end{array}$ & $7.2-8.8$ & $\begin{array}{ll}500 & - \\
740\end{array}$ & $900-1350$ & - & - & {$[3]$} \\
\hline $\begin{array}{l}\text { Dairy } \\
\text { wastewater }\end{array}$ & $890 \pm 14$ & $\begin{array}{l}216.17 \pm \\
4.17\end{array}$ & $\begin{array}{l}6.035 \quad \pm \\
0.065\end{array}$ & - & & $\begin{array}{l}69.96 \pm \\
1.16\end{array}$ & $\begin{array}{l}69.96 \pm \\
1.16\end{array}$ & {$[26]$} \\
\hline whey & 71526 & 20000 & & 22050 & 56782 & & - & {$[27]$} \\
\hline $\begin{array}{l}\text { Dairy } \\
\text { wastewater }\end{array}$ & $\begin{array}{l}2,500- \\
3,000\end{array}$ & $\begin{array}{l}1,300- \\
1,600\end{array}$ & $7.2-7.5$ & $\begin{array}{l}72,000- \\
80,000\end{array}$ & $\begin{array}{l}8,00- \\
10,000\end{array}$ & - & - & [28] \\
\hline
\end{tabular}

Feed water composition is among one of the factors influencing fouling. Proteins show amphoteric or hydrophobic behaviour and can easily adsorb on hydrophobic membranes, but the extent and rate of adsorption depends on the nature of dairy proteins, protein type, the ionic concentration and $\mathrm{pH}$ [61]. The presence of many ions in the solution shields the charged ions of protein molecules exposure from one another and result in high transmission [62].

High ionic strength and low $\mathrm{pH}$ favours fouling due to compression and deprotonation effect. Fouling is very high in a low $\mathrm{pH}$ or high ionic strength condition during UF of proteins. The electrical double layer (EDL) of protein molecules is compressed by high ionic strength. Because of this effect, protein molecules become small and tend to aggregate to form fouling. Functional groups in proteins undergo deprotonation at low $\mathrm{pH}$. This decreases the repulsive force of protein molecules and lead to fouling [46][48][50].

During BSA filtration protein fouling is strongly associated with zeta potential of BSA which is affected by $\mathrm{pH}$. Around isoelectric points (IEP) of BSA ( $\mathrm{pH} 4.7$ ), BSA molecules tend to come together due to low repulsion force. Therefore, the fouling mechanism is expected to be complete blocking and standard blocking. However, at higher $\mathrm{pH}$ both BSA and membrane are negatively charged and repel each other, reducing sever fouling of BSA, but cake layer could be formed slowly.

The impact of ionic strength on fouling depends on $\mathrm{pH}$. At $\mathrm{pH} 3.0$ and 5.8 an increasing and decreasing fouling trend were observed as ionic concentration went up from 1 to 10 and then to $100 \mathrm{mM} \mathrm{NaCl}$ while it did not show substantial effect at $\mathrm{pH} 4.7$ and 7. The lowest flux throughout the ionic strength were observed at $\mathrm{pH} 4.7$ [51]. Another fouling mitigation mechanism may be a charge shielding effect. This is obtained by increasing ionic strength and reduced protein deposition [52].

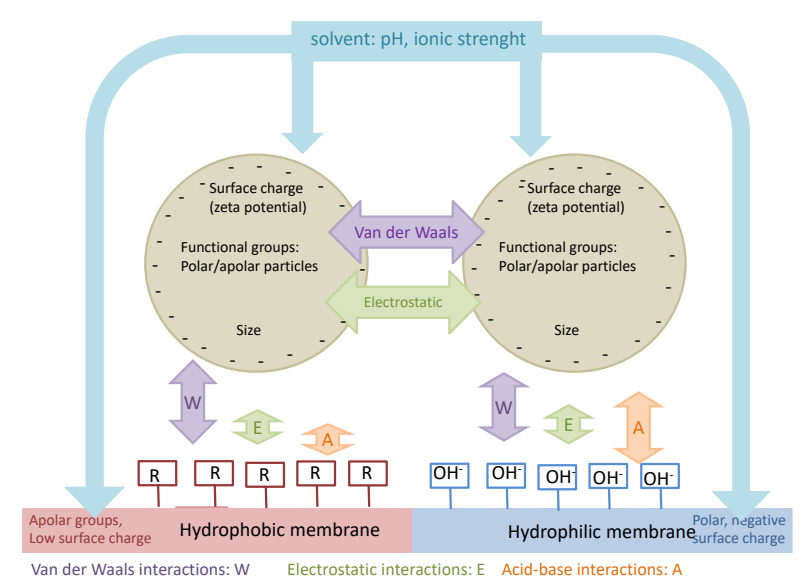

Fig. 3. Membrane-solute interactions

\section{Hydrodynamic parameters}

Velocity, trans-membrane pressure (TMP) and temperature are among hydrodynamic operating conditions that have effect on fouling. For example, low TMP results in not only lower fouling but also lower flux [53]. However, BSA fouling may be becoming severe as long as applied pressure increased; flux reductions were obtained $70.4 \%, 81.6 \%$, and $92.2 \%$ at $100 \mathrm{kPa}, 200 \mathrm{kPa}$, and $500 \mathrm{kPa}$, respectively, compared to only $28.5 \%$ reduction at $20 \mathrm{kPa}$ [53], due to building up more compact protein layer on the membrane surface.

Flux performance was also investigated at various levels of velocities $(13.9,27.8$, and $41.7 \mathrm{~cm} / \mathrm{s})$. Results indicated that flux reduction was decreased at increasing velocity. In this study best flux was obtained at the highest velocity (41.7 $\mathrm{cm} / \mathrm{s}$ ) which is about $137.4 \mathrm{~L} / \mathrm{m}^{2} \mathrm{~h}$ ) as compared with the flux $51.0 \mathrm{~L} / \mathrm{m}^{2} \mathrm{~h}$ at $13.9 \mathrm{~cm} / \mathrm{s}$ and $74.7 \mathrm{~L} / \mathrm{m}^{2} \mathrm{~h}$ at $27.8 \mathrm{~cm} / \mathrm{s}$. Application of higher crossflow velocities is advantageous in terms of possibility of improved back transport and the reduction of concentration polarisation. Therefore, more extended fouling take place above the critical flux and lower crossflow [54]. The permeability of a membrane remains 
almost constant with insignificant foulant deposition when the filtration is performed below the critical flux [55].

The effect of temperature is also one of the operational factors that can significantly affect fouling. BSA filtration at various temperatures was studied using ultrafiltration membrane. The outcome of the finding revealed that the membrane fluxes were declined from 0.68 at $20^{\circ} \mathrm{C}$ to 0.43 , 0.30 , and 0.28 at 27,34 , and $80{ }^{\circ} \mathrm{C}$, respectively [46]. The influence of temperature can be explained by whey protein membrane fouling which was larger at temperatures less than $10{ }^{\circ} \mathrm{C}$ and more than $35^{\circ} \mathrm{C}[30]$. Both extreme temperatures affect protein structures and allow hydrophobic interactions that lead to protein deposition [56]. Denatured proteins aggregate and foul easily as compared with decreases protein solubility compared to normal protein [57].

Based on their materials they are produced membranes can be fabricated from polymeric or ceramic materials [58]. Filtration using polymeric membranes are more preferred than ceramic membranes because of low cost, no harmful byproducts and can easily integrate with other methods [59]. However, polymeric membrane materials severely fouled by proteins [6]. Conventional polymers used for polymeric membrane manufacturing include polysulfone (PSF), polyethersulfone (PES), polyacrylonitrile (PAN), polyvinylidene fluoride (PVDF), cellulose acetate (CA) and polytetrafluoroethylene (PTFE) [59][60].

\subsection{Fouling control and mitigation strategies}

\subsubsection{Physical methods}

Physical cleaning changes hydrodynamics to a given solution to prevent foulant deposition on the membrane material. These methods may include cross-flow, hydraulic flushing, shearing, field (electric, ultrasonic, magnetic), concentration polarization absorber and adding activated carbon [63]. Backflush and backwash are commonly applied physical cleaning technologies. Unfortunately, these technologies require longer processing time [64].

By introducing vibration, it is possible to get an increased shear rate, which can reduce the membrane fouling and improve flux [65] [66]. The cleaning mechanism of vibration is achieved by generating an increased turbulence and shear forces on the membrane surface, to loosen and remove the deposits [67]. A study by Altaee et.al., 2010 [67] revealed that fouling cleaning efficiency was enhanced with increased vibration frequency. The increased vibration frequency from 1.67 to $8.35 \mathrm{~Hz}$ leads to an increased critical flux from 27 to $56 \mathrm{~L} /\left(\mathrm{m}^{2} \mathrm{~h}\right)$ compared to $15 \mathrm{~L} /\left(\mathrm{m}^{2} \mathrm{~h}\right)$ without. Li et al. 2013 has also reported that membrane performance can be significantly improved when the vibration frequency or vibration amplitude increases above a threshold magnitude. Over $90 \%$ membrane cleaning efficiency was attained at 8 $\mathrm{mm}$ amplitude and $8 \mathrm{~Hz}$ frequency vibration compared to no vibration [68].

Ultrasound is another physical method, and it has been applied for membrane cleaning in membrane filtration processes [72][76][77]. Ultrasound provides strong mixing both at a macroscopic (strong convective currents) and microscopic level (micromixing, pressure shockwaves, and microjetting). The strong convective currents known as acoustic streaming bring about increased fluid motion and turbulent mixing. At a microscopic level, there are physical effects from the collapse of cavitation bubbles that generate micromixing, pressure shockwaves, and micro jetting.

It is effective in reducing the concentration polarization and eliminating cake layers on the membrane [74]. Ultrasonic membrane cleaning applies high-frequency sound waves to agitate the aqueous medium which in turn acts on the foulants adhering to the membrane surface [75]; application of frequency between $20-28 \mathrm{kHz}$ performed the best to control PVDF membrane fouling [69]. A study by Lee et.al.,[70] showed outstanding performance of ultrasound as compared to flushing alone. $\mathrm{Yu}$ [71] also indicated reduction of reversible and irreversible fouling by ultrasound. The performance of ultrasound can also improve by combining with other cleaning processes, like surfactant [64]. Unlike backwashing or chemical cleaning, ultrasonication can be integrated in the filtration process without stopping the filtration; since it does not use chemicals and backwashing water; it avoids the difficulties of chemical costs, waste disposal and environmental concerns [72].

In terms of fouling mechanism, ultrasonic enhancement of membrane filtration showed four main effects on whey protein fouling [76]. Firstly, sonication reduces pore blockage and cake compaction by promoting the agglomeration of fine particles. Secondly, sonication maintains particles suspended by providing mechanical vibrational energy to the system. Thirdly, sonication induces small vapour-filled cavities known as cavitation bubbles that scour the membrane surface and can reach areas not accessible to conventional cleaning methods. Finally, acoustic streaming causes turbulence and more intense mixing, which will result bulk fluid movement toward and away from the membrane cake layer.

\subsubsection{Chemical cleaning}

Chemical cleaning is a kind of using chemical agents that degrade the foulant or reduce the attractive force between the molecules of the solution and membrane [78]. It is mainly used to clean hydraulically irreversible foulants. It can be applied in various ways; firstly by cleaning the membrane by replacing the original feed with cleaning solution within the membrane reactor referred as cleaning-in-place (CIP), secondly by soaking the membrane in a separate tank outside the reactor, known to as cleaning out of place (COP), thirdly by adding chemicals in the feed stream, fourthly cleaning the membrane in physic chemical combination [79]. The chemicals could be acids, alkaline and oxidants. Commonly applied chemicals for membrane cleaning are sodium hydroxide, sodium hypochlorite, hydrochloric acid, sulfuric acid, nitric acid, ethylene domain tetra acetic acid and sodium dodecyl sulphate. Study results have shown that alkaline chemicals offer better cleaning performance in milk processing industry as compared to acids [78]. However chemical cleaning may damage the membrane, generate effluents and are expensive [80].

During chemical cleaning of membrane fouled by milk components cleaning agent diffuses into the fouled membrane surface and undertake chemical reaction between the cleaning agent and the deposited materials at the membrane surface. The reaction may be hydrolysis, dissolution or dispersion which results in removal of fouling materials from the membrane surface [81]. Alkaline offer better cleaning performance in milk processing industry as compared to acids, moreover combinations of chelating agent, surfactant and alkaline provide the best cleaning efficiency [81]. Ethylenediaminetetraacetic acid (EDTA) as a chelating agent has an outstanding ability to combine and form strong complexes with multivalent metal ions such as calcium and minerals in general. The effect of sodium dodecyle sulfate (SDS) as a surfactant can bring a change in interfacial tension of water. This results in superior separation of build-up materials from the membrane surface. Sodium hydroxide 
$(\mathrm{NaOH})$ alters $\mathrm{pH}$ of the solution and offers a favourable condition for the highest removal of foulants using EDTA and SDS [80][82].

An other study demonstrated, that alkaline, such as sodium hydroxide $(\mathrm{NaOH})$, potassium hydroxide $(\mathrm{KOH})$ can facilitate quick hydrolysis of proteins and polysaccharides into small amides and sugars; reduces the number of bonds between the foulant and the membrane surface and increase mass transfer of cleaning agents to the membrane surface. Acids such as hydrochloric acid $(\mathrm{HCl})$, nitric acid $\left(\mathrm{HNO}_{3}\right)$ and sulphuric acid $\left(\mathrm{H}_{2} \mathrm{SO}_{4}\right)$ can perform efficiently and effectively dissolve precipitates of inorganic salts and metal oxides or hydroxides [83].

\subsubsection{Physicochemical cleaning}

Physicochemical methods are the most used cleaning process. For instance, chemically enhanced backwashing (CEB) is widely used physicochemical method, in this case chemicals are used during backwashing [79].

One of the recent fouling cleaning trends is integrating physical and chemical cleaning in membrane cleaning processes. A research showed that effective chlorine addition $(0.2-0.5 \mathrm{mg} / \mathrm{L})$ and backwash at flux of $8.33 \mathrm{~L} /\left(\mathrm{m}^{2} \mathrm{~h}\right)$ reduced fouling rates by $63-77 \%$ compared to normal water backflushing in membrane bioreactors (MBRs) [84], while Zhou et al. 2014 reported that $0.01 \mathrm{~mol} / \mathrm{L} \mathrm{NaOH}$ at $0.3 \mathrm{~h}$ duration and backwash flux $8.33 \mathrm{~L} /\left(\mathrm{m}^{2} \mathrm{~h}\right)$ could reduce fouling rate by $50 \%$ compared to water backwashing method in MBRs [85].

The study carried out by Maskooki et al. [86] demonstrated that using lower frequencies of ultrasound associated with EDTA is more effective than using each measure separately. The flux recovery rate by this physicochemical cleaning was about 4-10 times that of single ultrasound or EDTA cleaning.

\subsubsection{Pre-treatment}

In membrane separation processes pre-treatment is necessary to ensure reliable membrane operation, reduce membrane fouling risk and prolong membrane life. The extent of fouling risk reduction varies with type of pre-treatment method. Coagulation method is an attractive method for the removal of particles and dissolved contaminants but ineffective in removing the neutral hydrophilic and low molecular weight fractions [87].

Physicochemical pre-treatments such as coagulation/flocculation and oxidation practice have been used to reduce wastewater contaminants. However, they are expensive and poor in terms of contaminant removal [88]. They also generate chemical sludge that require additional treatment and require $\mathrm{pH}$ adjustment [89].

Oxidation pre-treatments such as use of ozone, ultraviolet (UV) radiation with hydrogen peroxide $\left(\mathrm{H}_{2} \mathrm{O}_{2}\right)$ and ultraviolet (UV) radiation with persulfate (PS) were also applied as the pre-treatments for UF process. Among these pre-treatment methods ultraviolet (UV) and persulfate (PS) combination offered an outstanding result in mitigating membrane fouling and contaminant removal. This performance may be associated with PS, a powerful oxidant, ability to produce sulphate radicals $\left(\mathrm{SO}^{-}\right.$) by catalyser activation in water. [90]. Combination of ferrous ion (Fe(II)) and sodium percarbonate (SPC) were performed better membrane fouling control than using each of them alone because Fe(II) serves as catalyst to activate SPC oxidation [91].
Pre-treatment of wastewater before ultrafiltration were investigated using advanced oxidation processes, that is, ultraviolet together with ferrous ion, ultraviolet together with persulfate, ferrous ion together with persulfate and combination of ultraviolet, ferrous ion and persulfate. The best performance was shown by combination of ultraviolet light, ferrous ion and persulfate followed by ferrous ion and persulfate. The lowest performance was observed in the combination of ultraviolet pre-oxidation together with ferrous ion pre-coagulation [92] as $\mathrm{Fe}$ (II) has high tendency to oxidize rapidly to $\mathrm{Fe}(\mathrm{III})$ in a reaction and the catalytic effect may decrease at neutral $\mathrm{pH}$ [93]. Degradation experiments of free-radical scavenger addition (sodium hyposulfite or tertbutanol) showed that the sulphate radical (SO4 ${ }^{-\bullet}$ ) was dominant in degrading organic compounds but the release of $\mathrm{Fe}(\mathrm{III})$ from water under UV radiation and its possible conversion to $\mathrm{Fe}$ (II) were observed on the surface of the fouled membranes and this caused decreased catalytic effect [92].

Combination of different methods such as disinfection, scale inhibitor (acid), activated carbon, coagulation/flocculation, and membrane filtration (UF)/MF) are widely used as effective pre-treatment methods for reverse osmosis (RO) [94]. In these processes, each pre-treatment methods control some contaminant for example part disinfection can destroy microorganisms which may cause diseases and membrane biofouling. Scale inhibitor (acid) remove inorganic molecules to control inorganic fouling. Activated carbon remove dissolved organic carbon (DOC) to control organic fouling. Coagulation/flocculation removes colloidal particles and dissolved organic carbon (DOC), while membrane filtration (UF)/MF) removes colloids, particles, and microorganism to control colloidal fouling, organic fouling and biofouling.

\subsubsection{Membrane modification}

Membrane surface is a part of the membrane that contacts the feed. Its properties basically determine the membrane performance. Membrane improvement has been performed by coating it with semiconductor heterogeneous photocatalysts or using hydrophilic polymers such as polyethylene glycol (PEG), polyvinylpyrrolidone (PVP) and poly(methyl methacrylate) (PMMA) and so on [95].

Membrane modification is intended to reduce fouling in dairy protein separation processes by changing the chemical nature and pore size of the membrane.[96][97].

\section{Membrane modification by semiconductor heterogeneous photo-catalysts}

Heterogeneous photocatalysis is a process, which transfer light energy into other form of chemical energy to use for several applications, particularly water and wastewater purification. It is able to degrade a many type of organic contaminants and mineralize the contaminant into water and carbon dioxide [98]. Heterogeneous photocatalysis do not transform the contaminant from one phase to another like coagulation and flocculation process, instead it eliminates the contaminants by mineralization. The basics of heterogeneous photocatalysis are summarized in Fig. 4.

Based on the energy source, the nano-catalysts used could be photocatalysts and electrocatalysts [99], and Fenton based catalysts [100]. They enhance the degradation of organic contaminants [101] and microbial foulants [102].

Because of the many drawbacks associated with physical and chemical cleaning technique, nanostructured photocatalysts, such as tungsten-oxide $\left(\mathrm{WO}_{3}\right)$ [103], bismuth- 
oxide $\left(\mathrm{Bi}_{2} \mathrm{O}_{3}\right)$ [104], titania $\left(\mathrm{TiO}_{2}\right)$ [105][106], zinc-oxide $(\mathrm{ZnO})$ [107], graphene oxide $(\mathrm{GO})$ [108], zirconia $\left(\mathrm{ZrO}_{2}\right)$ [109]106], alumina $\left(\mathrm{Al}_{2} \mathrm{O}_{3}\right)$ [109], and silica $\left(\mathrm{SiO}_{2}\right)$ [110] have been gaining considerable attention to enhance the hydrophilic and surface free energy character of the membrane surface.

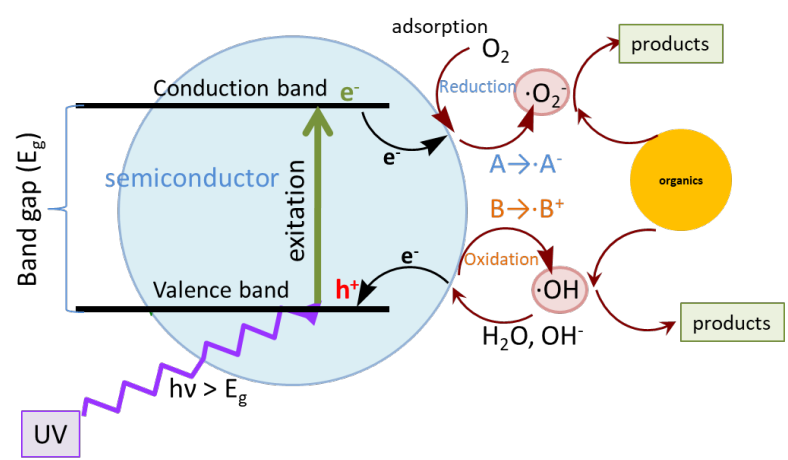

Fig. 4. Mechanism of heterogeneous photocatalysis

The photocatalyst titanium dioxide $\left(\mathrm{TiO}_{2}\right)$ is superior as compared with other photocatalysts, because it has excellent physical and chemical characteristics, low cost, high photocatalytic reactivity below $390 \mathrm{~nm}$ ultraviolet light required for most photocatalysis reactions, desirable hydrophilic and potential antifouling properties [111], [112]. It also has superior benefits to advanced oxidation processes. It is stable under photo and chemical exposure, cheap, reusable, and non-toxic [113]. Rutile, anatase, and brookite are the three structure polymorphs of titania; anatase shows the highest photocatalytic reactivity due to its lower recombination rate of electron-hole pairs [114]. For high photocatalytic performance, high anatase contents and relatively large specific surface areas for the coatings are required.

Since $\mathrm{ZnO}$ has a wide band gaps, similarly to $\mathrm{TiO}_{2}$, it has also been widely studied for photocatalysis [115]. Like polymer- $\mathrm{TiO}_{2}$, polymer-ZnO composite membranes attracted the attention of researchers in membrane technology. Zincoxide $(\mathrm{ZnO})$ nanoparticles are a low-cost, environmentfriendly, and hydrophilic inorganic material, that can provide composite polymeric membranes with excellent antifouling performance and photocatalytic self-cleaning benefits, furthermore it has comparable physical and chemical properties to $\mathrm{TiO}_{2}[116][117]$.

Effects of membrane modification on fouling: enhancement by their properties and surface charge

Scaling and organic fouling are longstanding problems in RO membrane-based desalination, which requires frequent chemical cleaning, increases operation cost, and adversely impact the environment [118][119]. Membrane surface properties, including surface wettability, charge, and functionality, are the main factors governing the scaling and organic fouling on the membrane surface [120]. Tong et al., [120] revealed that surface functional groups with positive charge attract negatively charged dissolved silica species, thus accelerating silica scaling on the membrane surface. Hence, membrane fabrication or surface modification that can control scaling and fouling at the same time would be highly advantageous for more productive RO desalination.
More negatively surface charged membranes (-COOH), acrylic acid (AA) membranes were fabricated through redox free radical grafting method. Ethylamine (EA) and ethylenediamine (ED) membranes with neutral or less negative surface charge were fabricated through $-\mathrm{CH}_{3}$ or $-\mathrm{NH}_{2}$ functional groups grafting aimed in improving antifouling or anti-scaling properties. Compared to the pristine membrane, all the modified membranes possessed better salt rejection without sacrificing water permeability. The AA membrane also showed better antifouling property, less silica scaling and organic foulants [121].

Functionalized surface of thin-film composite (TFC) RO membranes by negative surface charge of sulfonic group (vinyl sulfonic acid) mitigates negatively charged silica scaling. It also effectively hinders bridging between organic foulant and the membranes [112]. Amine-functionalized osmotic membranes were fabricated by optimizing the grafting pathway of polyamidoamine (PAMAM) dendrimer to mitigate fouling and ammonium transmembrane diffusion. Compared to the control membrane, the PAMAM-grafted membranes with abundant primary amine group showed significantly increased hydrophilicity and positive charges (i.e., protonated primary amines) and thus exhibited superior anti-fouling capability and ammonium selectivity and eventually achieved an ultra-high ammonium rejection of $99.4 \%$ [123].

Farahani \& Vatanpour [124] compared pristine PVDF membrane with different loading of cloisite 30B clay, carboxyl- functionalized multi-walled carbon nanotubes, Silicon dioxide and titanium oxide). Pure water flux improvement for clay, MWCNTs-COOH, $\mathrm{SiO}_{2}$, and $\mathrm{TiO}_{2}$ was $187 \%, 143 \%, 50 \%$, and $111 \%$, respectively. Because of hydrophilicity enhancement, the modified membranes showed better antifouling properties. Unlike clay and $\mathrm{TiO}_{2}$ modified membranes MWCNTs-COOH and $\mathrm{SiO}_{2}$ modified membranes showed better BSA rejection compared to pristine PVDF membrane. High loading of nanoparticles resulted in lower performance of the modified membrane by increasing dope viscosity, agglomeration and blocking the pores. In an other study, Susanto et.al.[125] compared three modified polyether sulfone (PES) ultrafiltration membranes. The highest flux and the lowest flux reduction were observed in case of $\mathrm{PES} / \mathrm{TiO}_{2} 3 \mathrm{wt} \%$ which was followed by $\mathrm{ZnO} 5 \mathrm{wt} \%$.

\section{Challenges and possible solutions}

Nowadays fouling becomes a threat to a conventional polymeric membranes' application. Self-cleaning photocatalytic polymeric membranes have been shown better resistance to fouling [124]. However, electron/hole recombination and low photo-efficiency are the two disadvantages that limit its practical application. In photocatalysis, low photo-efficiency can be improved by utilising the solar/visible light spectrum.

The electron/hole recombination resulted in waste of energy. Several approaches have been applied for tackling the quantum inefficiency of a photocatalyst [126]. First, by using oxidants because the addition of oxidants adds acceptors of electrons in the process and increases the number of trapped electrons. Second by doping, pure and unmodified semiconductor surface like $\mathrm{TiO}_{2}$ use only the UV spectrum and works at calm conditions with weak oxidants. So unmodified photocatalyst for practical treatment applications of industrial and environmental effluents of higher concentration of contaminants may require high costs 
associated with artificial light. Hence, the drawbacks of unmodified photocatalyst must be solved by combining the photocatalyst with semiconductor with a narrower bandgap or doping the photocatalyst with a transitional metal ion, sulphur, nitrogen, and noble metals [126].

Applying photosensitizer on the surface of photocatalyst also may be an effective method. The photosensitizer does not act as a photocatalyst, instead, facilitate the semiconductor to carry out reaction using visible light by injecting its exited electrons to the conduction band of semiconductor. A photosensitizer is vital in industrial textile wastewaters as these wastewaters consist of a large number of dyes [104]. Graphene and carbon nanotubes are also reported to behave as photosensitizers under visible light by transforming wide band gap of the semiconductor to a visible light photocatalyst [127].

Another way of enhancing the photocatalytic efficiency is combining photocatalyst with other technologies, including ozone treatment, vacuum ultraviolet treatment or photocatalytic membrane reactor (PMR)[128]. Many researchers have reported several nanomaterials with photocatalytic activities using visible light. These are nanoparticles and quantum dots of cadmium sulphide (CdS) [129], bismuth vanadate $\left(\mathrm{BiVO}_{4}\right)$ [130], and nanocubes of silver-chloride $(\mathrm{AgCl})$ [131], copper sulphide nanostructures (CuS NSs) [132], semiconductor $\beta$ phase bismuth oxide ( $\beta$ $\mathrm{Bi}_{2} \mathrm{O}_{3}$ ) [133], iron (Fe) (III) and active carbon [134].

\section{Conclusions}

Considerable volume and high pollution load of effluent is generated by food industries especially dairy industry. In dairy wastewater, proteins tack the lion share of fouling during polymeric membrane separation processes. Proteins are amphoteric molecules; the charge of their surface depends on the solution $\mathrm{pH}$. Membrane separation processes may be advantageous to treat wastewater of dairy industries, however, fouling issue limits their widespread application. Membrane fouling may be influenced by several factors, operating parameters, feed water composition, and membrane properties. Fouling in dairy wastewater treatment is primarily relying on the salt and the type of protein present.

Membrane separation processes offer possibilities to reuse dairy industrial wastewater effluent. Membrane fouling can be controlled and mitigated through physical, chemical, physicochemical, pre-treatment and self-cleaning membranes. Self-cleaning membrane is a promising method over the other methods because of low cost, less time, less ecological footprint, and efficient contaminant removal.

Chemical oxidants, doping, photosensitizers, combining semiconductor photocatalysis with other AOPs are the most promising techniques applied to tackle electron/hole recombination and low photo-efficiency of heterogenous photo-catalytic materials.

Cadmium sulphide $(\mathrm{CdS})$, bismuth vanadate $\left(\mathrm{BiVO}_{4}\right)$, nanocubes of silver chloride $(\mathrm{AgCl})$, copper sulphide nanostructures (CuS NSs), semiconductor $\beta$ phase Bismuth oxide $\left(\beta-\mathrm{Bi}_{2} \mathrm{O}_{3}\right)$, Iron (Fe) (III) and active carbon are nanomaterials that can perform their photocatalytic activities using visible-light. Visible-light or solar energy driven photocatalysis applicable in a more extensive environmental conditions can be achieved through doping and modifications of membranes by heterogeneous photo-catalytic materials.

\section{Acknowledgements}

The authors gratefully acknowledge for the financial support of the Hungarian State and the European Union (EFOP-3.6.216-2017-00010), Hungarian Science and Research Foundation (2017-2.3.7-TÉT-IN-2017-00016).

This is an Open Access article distributed under the terms of the Creative Commons Attribution License.

\section{References}

1. N. Mancosu, R.L. Snyder, G. Kyriakakis, and D. Spano, Water scarcity and future challenges for food production. Water 7, 975-992 (2015).

2. C.F. Bustillo-Lecompte and M. Mehrvar. Slaughterhouse wastewater characteristics, treatment and management in the meat processing industry: a review on trends and advances. J Environ. Manag. 161, 287-302 (2015).

3. U.B. Deshannavar, R.K. Basavaraj, \& N.M. Naik. High-rate digestion of dairy industry effluent by upflow anaerobic fixed-bed reactor. Journal of Chemical and Pharmaceutical Research, 4(6), 2895-2899 (2012).

4. M.B.S.Shete. Comparative Study of Various Treatments For Dairy Industry Wastewater. IOSR Journal of Engineering, 03(08), 42-47 (2013).

5. B. V Raghunath, A. Punnagaiarasi, G. Rajarajan, A. Irshad, A. Elango, G. Mahesh Kumar, Impact of Dairy Effluent on Environment-A Review. Environmental Science and Engineering, 239-249. (2016)

6. S.S. Madaeni, Y. Mansourpanah. Screening membranes for COD removal from dilute wastewater. Desalination, 197(1-3), 23-32 (2006).

7. M. Xie, H.K. Shon, S.R. Gray, M. Elimelech, Membrane-based processes for wastewater nutrient recovery: Technology, challenges and future direction. Water Research 89. pp. 210-221 (2016):

8. S. Guerra-Rodriguez, P. Oulego, E. Rodriguez, D.N. Singh, J. Rodriguez-Chueca, Towards the Implementation of Circular Economy in the Wastewater Sector: Challenges and Opportunities. Water, 12, 1431(2020).

9. Y. Wang, L. Serveti, Sustainability of dairy and soy processing: A review on wastewater recycling, J. Cleaner Production, 237117821 (2019)
10. C.M. Mehta, W.O. Khunjar, V. Nguyen, S.Tait, D.J. Batstone, Technologies to recover Nutrients from Waste Streams: ACritical Review. Crit. Rev. Environ. Sci.Technol. 45, 385-427 (2015).

11.Y.W. Gong, H.X. Zhang \& X.N.\& Cheng. Treatment of dairy wastewater by two-stage membrane operation with ultrafiltration and nanofiltration. Water Science and Technology, 65(5), 915-919 (2012).

12.Y.R. Chang, Y.J. Lee, D.J. Lee, Membrane fouling during water or wastewater treatments: Current research updated. Journal of the Taiwan Institute of Chemical Engineers, 94, 88-96. (2019).

13. T. Ahmad, R.M. Aadil, H. Ahmed, U. Rahman, B.C.V. Soares, S.IQ. Souza, ... A.G. Cruz, Treatment and utilization of dairy industrial waste: A review. Trends in Food Science \& Technology. 88, 361372 (2019).

14. B. Das, S. Sarkar, A. Sarkar, S. Bhattacharjee, C. Bhattacharjee, Recovery of whey proteins and lactose from dairy waste: A step towards green waste management. Process Safety and Environmental Protection, 101, 27-33. (2016).

15. S. Abdelkader, F. Gross, D. Winter, J. Went, J, Koschikowski, S. U. Geissen, L. Bousselmi, Application of direct contact membrane distillation for saline dairy effluent treatment: performance and fouling analysis. Environmental Science and Pollution Research. 26, 18979-18992. (2019)

16. B. Sarkar, P.P. Chakrabarti, A. Vijaykumar, V. Kale, Wastewater treatment in dairy industries - possibility of reuse. Desalination, 195(1-3), 141-152. (2006).

17. A.C. Bortoluzzi, J.A. Faitão, M. Di Luccio, R.M. Dallago, J. Steffens, G.L. Zabot, M.V. Tres, Dairy wastewater treatment using integrated 
membrane systems. Journal of Environmental Chemical Engineering, 5(5), 4819-4827. (2017).

18. A.S. Kolhe, S.R. Ingale, R.V.Bhole, The effluent of Dairy Technology. International Research Journal, II (5), 459-461 (2002).

19. R. Atra, G. Vatai, E. Bekássy-Molnár, A. Bálint, Investigation of ultra- and nanofiltration for utilization of whey protein and lactose, J. Food Eng. 67, 325-332 (2005).

20. D.J. McMahon, B.S.Oommen, Supramolecular Structure of the Casein Micelle. Journal of Dairy Science, 91(5), 1709-1721. (2008).

21. H.M. Farrell, R. Jimenez-Flores, G.T. Bleck, E.M. Brown, J.E. Butler, L.K. Creamer, H.E. Swaisgood, Nomenclature of the Proteins of Cows' Milk-Sixth Revision. Journal of Dairy Science, 87(6), 1641-1674. (2004).

22. K.S.Y. Ng, M. Haribabu, D.J.E. Harvie, D.E. Dunstan, G.J.O. Martin, Mechanisms of flux decline in skim milk ultrafiltration: A review. Journal of Membrane Science, 523, 144-162. (2017).

23. P. Kumar, N. Sharma, R. Numar, S. Ranjan, Z.F. Bhat, D.K. Jeong, Perspective of Membrane Technology in Dairy Industry: A review, Asian Australian J. Anim. Sci. 26(9) 1347-1358. (2013).

24. A.K. Slavov, General Characteristics and Treatment possibilities of Dairy Wastewater - A Review, Food Technol and Biotechnol, 55(1), 14-28 (2017).

25. J.T.Britz, C. van Schalwyk, Y.T. Hung, Treatment of dairy processing wastewaters. In: Wang L.K., Hung, Y.T., Lo, H.H., Yapijakis, C., editors. Waste treatment in the food processing industry. Boca Raton, FL. USA: CRC Press; 2006. 1-25. (2006).

26. A. Krishan, A. Srivastava, Recovery of Nutrients from Dairy Wastewater by Struvite Crystallization, 3(5), 591-597(2015)..

27. D.P. Deshpande, P.J. Patil, S.V. Anekar, Biomethanation of Dairy Waste. Research Journal of Chemical Sciences, 2(4), 35-39 (2012).

28. J.I. Qazi, M. Nadeem, S.S. Baig, S. Baig, Q. Syed, Anaerobic fixedfilm biotreatment of dairy wastewater. Middle-East Journal of Scientific Research, 8(3), 590-593 (2011).

29. D. Bixio, C. Thoeye, J. De. Koning, D. Joksimovic, D. Savic, Wastewater reuse in Europe, 187(February 2005), 89-101. (2006).

30. T. Steinhauer, S. Hanély, K. Bogendörfer, U. Kulozik, Temperature dependent membrane fouling during filtration of whey and whey proteins. Journal of Membrane Science, 492, 364-370 (2015).

31. F.L .Silva, G. Zin, K. Rezzadori, L.C. Longo, L. Tiggemann, L.S. Soares, M. De Luccio, Changes in the physicochemical characteristics of a protein solution in the presence of the magnetic field and the consequences on the ultrafiltration performance. Journal of Food Engineering, 242(February 2018), 84-93 (2019).

32. L.H. Andrade, F.D.S. Mendes, J.C. Espindola, M.C.S. Amaral, Nanofiltration as tertiary treatment for the reuse of dairy wastewater treated by membrane bioreactor. Separation and Purification Technology, 126, 21-29 (2014).

33. M. Vourch, B. Balannec, B. Chaufer, G.Dorange, Treatment of dairy industry wastewater by reverse osmosis for water reuse. Desalination, 219(1-3), 190-202 (2008).

34. D.F. Galvão, Membrane Technology and Water Reuse in a Dairy Industry. Technological Approaches for Novel Applications in Dairy Processing (DOI: 10.5772/intechopen.76464) (2018).

35. S.Velpula, K.S. Umapathy, A.Thyarla, K. Srikanth, S.Saraff, Dairy Wastewater Treatment by Membrane Systems-A Review, Int. J. Pure App. Biosci. 5(6), 389-395. (2017).

36. G.M. Geise, H.S. Lee, D.J. Miller, B.D. Freeman, J.E. McGrath, D.R. Paul, Water purification by membranes: The role of polymer science. Journal of Polymer Science Part B: Polymer Physics, 48(15), 16851718. (2010).

37. Z. Wang, J. Ma, C.Y. Tang, K. Kimura, Q. Wang, X. Han. Membrane cleaning in membrane bioreactors: A review. Journal of Membrane Science, 468, 276-307. (2014).

38. W. Yang, N. Cicek, J. Ilg, State-of-the-art of membrane bioreactors: Worldwide research and commercial applications in North America. Journal of Membrane Science, 270(1-2), 201-211. (2006).

39. M. Elimelech, W.A. Phillip, The Future of Seawater. Science, 333(August), 712-717(2011).

40.C.Y. Tang, T.H. Chong \& A.G.Fane Colloidal interactions and fouling of NF and RO membranes: A review. Advances in Colloid and Interface Science, 164(1-2), 126-143. (2011).

41. J.S. Louie, I. Pinnau, I. Ciobanu, K.P. Ishida, A. Ng, M. Reinhard, Effects of polyether-polyamide block copolymer coating on performance and fouling of reverse osmosis membranes. Journal of Membrane Science, 280(1-2), 762-770. (2006).

42. Y. Yu, S. Lee, S. Hong. Effect of solution chemistry on organic fouling of reverse osmosis membranes in seawater desalination. Journal of Membrane Science, 351(1-2), 205-213 (2010).
43. K. Xiao, X. Wang, X, Huang, T.D. Waite, X. Wen, Combined effect of membrane and foulant hydrophobicity and surface charge on adsorptive fouling during microfiltration. Journal of Membrane Science, 373(1-2), 140-151. (2011).

44. I.H. Huisman, P. Prádanos, A. Hernández, The effect of protein protein and protein - membrane interactions on membrane fouling in ultrafiltration, 179, 79-90. (2000).

45. A. Arunkuma, M.R. Etzel, Negatively charged tangential flow ultrafiltration membranes for whey protein concentration, 475, 340348. (2015).

46. Y. Ding, B. Ma, H. Liu, J. Qu, ScienceDirect Effects of protein properties on ultrafiltration membrane fouling performance in water treatment. Journal of Environmental Sciences, 77, 273-281. (2018).

47. A. Guadix, E.M. Guadix, M.C. Alm, Effect of $\mathrm{pH}$ on the fractionation of whey proteins with a ceramic ultrafiltration membrane, 288, 2835. (2007).

48. R. Navarro-Lisboa, C. Herrera, R.N. Zú, J. Enrione, F. Guzmán, S. Matiacevich, C. Astudillo-Castro, Food and Bioproducts Processing Quinoa proteins (Chenopodium quinoa Willd) fractionated by ultrafiltration using ceramic membranes: The role of $\mathrm{pH}$ on physicochemical and conformational properties, 2, 20-30. (2016).

49 .L. Wang, L. Wang, X. Ye, H.Yu. Hydration interactions and stability of soluble microbial products in aqueous solutions. Water Research, 47(15), 5921-5929. (2013).

50. R. Miao, L. Wang, N. Mi, Z. Gao, T. Liu, Y. Lv, Y. Yang, Enhancement and Mitigation Mechanisms of Protein Fouling of Ultra filtration Membranes under Different Ionic Strengths, 49, 6574-6580. (2015).

51. Q. She, C.Y. Tang, Y. Wang, Z .Zhang, The role of hydrodynamic conditions and solution chemistry on protein fouling during ultrafiltration. Desalination, 249(3), 1079-1087. (2009).

52. J. Lee, S. Jeong, Y. Ye, V. Chen, S. Vigneswaran, T. Leiknes, Z. Liu, Protein fouling in carbon nanotubes enhanced ultrafiltration membrane: Fouling mechanism as a function of $\mathrm{pH}$ and ionic strength. Separation and Purification Technology, 176, 323-334. (2017).

53. S. Jiang, Y. Zhang, F. Zhao, Z. Yu, X. Zhou \& H. Chu, Impact of transmembrane pressure (TMP) on membrane fouling in microalgae harvesting with a uniform shearing vibration membrane system. Algal Research, 35, 613-623. (2018).

54. C.Y. Tang, Y. Kwon, J.O. Leckie, Fouling of reverse osmosis and nanofiltration membranes by humic acid - Effects of solution composition and hydrodynamic conditions, 290, 86-94. (2007).

55. P. Bacchin, P. Aimar, R. Field, P. Bacchin, R.F. Aimar, Critical and sustainable fluxes: theory, experiments and applications, Journal of Membrane Science, 281, 42-69. (2006).

56. M. Thereza, M.G. Rosa, D.H.P. Guimarães, P.F. Arce, International Journal of Heat and Mass Transfer Experimental measurements and simulation of the fouling phenomena of natural proteins. International Journal of Heat and Mass Transfer, 129, 1075-1085. (2019).

57. D.H.G.Pelegrine, C.A.Gasparetto, A comparative study between ovalbumin and b -lactoglobulin fouling in a tube hot surface, 73, 394-401. (2006).

58. M. Zoubeik, I. Mohamed, S. Amgad, H. Amr, New Developments in Membrane Technologies Used in the Treatment of Produced Water: A Review, Arabian Journal for Science and Engineering 43(5), 2093-2118. (2017).

59. L.Y. Ng, W.M. Abdul, P.L. Choe, H. Nidal, Polymeric Membranes Incorporated with Metal/Metal Oxide Nanoparticles: A Comprehensive Review, Desalination 308, 15-33. (2013).

60. S. Adnan, M. Hoang, H. Wang, Z. Xie, Commercial PTFE membranes for membrane distillation application: Effect of microstructure and support material. Desalination, 284, 297-308. (2012).

61. A. Hausmann, P. Sanciolo, T. Vasiljevic, M. Weeks, K. Schroën, S.Gray, M.Duke, Fouling of dairy components on hydrophobic polytetrafluoroethylene (PTFE) membranes for membrane distillation. Journal of Membrane Science, 442, 149-159. (2013).

62. A. Persson, A. Jönsson, G. Zacchi, Transmission of BSA during cross-flow microfiltration: influence of $\mathrm{pH}$ and salt concentration, 223, 11-21. (2003).

63. D. Zhao, S. Yu, A review of recent advance in fouling mitigation of $\mathrm{NF} / \mathrm{RO}$ membranes in water treatment: pretreatment, membrane modification, and chemical cleaning. Desalination and Water Treatment, 55(4), 870-891. (2014).

64. S. Muthukumaran, K. Yang, A. Seuren, S. Kentish, M. Ashokkumar, G. Stevens, F. Grieser. The use of ultrasonic cleaning for 
ultrafiltration membranes in the dairy industry. Separation and Purification Technology, 39(1-2), 99-107. (2004)

65. Y. Li, M.R. Bilad, I.F.G. Vankelecom, Application of a magnetically induced membrane vibration (MMV) system for lignocelluloses hydrolysate filtration. Journal of Membrane Science, 452, 165-170. (2014).

66. A. Kola, Y.Ye, P. Le-Clech, V.Chen, Transverse vibration as novel membrane fouling mitigation strategy in anaerobic membrane bioreactor applications, Journal of Membrane Science, 455, 320-329 (2014).

67. A. Altaee, A.E. Al-Rawajfeh, Y.J. Baek, Application of vibratory system to improve the critical flux in submerged hollow fiber MF process, Sep. Sci. Technol. 45, 28-34. (2010).

68. T. Li, A.W.K. Law, M. Cetin, A.G. Fane, Fouling control of submerged hollow fibre membranes by vibrations. Journal of Membrane Science, 427, 230-239. (2013).

69. H.W.D. Camara, H. Doan, A. Lohi, In-situ ultrasound-assisted control of polymeric membrane fouling. Ultrasonics, 108, 106206. (2020).

70. S. Lee, H.K. Shon, S. Hong, Dewatering of activated sludge by forward osmosis (FO) with ultrasound for fouling control. Desalination, 421, 79- 88. (2017).

71. W. Yu, N. Graham, T. Liu, Effect of intermittent ultrasound on controlling membrane fouling with coagulation pre-treatment: Significance of the nature of adsorbed organic matter. Journal of Membrane Science, 535, 168-177. (2017).

72. S. Muthukumaran, K. Yang, A. Seuren, S. Kentish, M. Ashokkumar, G. Stevens, F. Grieser, The use of ultrasonic cleaning for ultrafiltration membranes in the dairy industry. Separation and Purification Technology, 39(1-2), 99-107. (2004).

73. M.J. Luján-Facundo, J.A. Mendoza-Roca, B. Cuartas-Uribe, S. Álvarez-Blanco, Membrane fouling in whey processing and subsequent cleaning with ultrasounds for a more sustainable process. Journal of Cleaner Production, 143, 804-813. (2017).

74. A.L. Ahmad, N.F. Che Lah, S. Ismail, B.S. Ooi, Membrane Antifouling Methods and Alternatives: Ultrasound Approach. Separation \& Purification Reviews, 41(4), 318-346. (2012).

75. A.S. Aghapour A. Taghipour, A. Rahimpour, A. Mollahosseini, A. Tiraferri, A Critical Review on Ultrasonic-Assisted Fouling Control and Cleaning of Fouled Membranes. Ultrasonics, 108, 106228. (2020).

76. S. Muthukumaran, S. Kentish, M. Ashokkumar, G. Stevens, Mechanisms for the ultrasonic enhancement of dairy whey ultrafiltration. Journal of Membrane Science, 258(1-2), 106114. (2005).

77. S. Muthukumaran, S.E. Kentish, G.W. Stevens, M. Ashokkumar, R. Mawson, The application of ultrasound to dairy ultrafiltration: The influence of operating conditions. Journal of Food Engineering, 81(2), 364-373. (2007).

78. M. Kazemimoghadam, T. Mohammadi, Chemical cleaning of ultrafiltration membranes in the milk industry. Desalination, 204(13), 213-218. (2007).

79. J.C.T. Lin, D.J. Lee, C.Huang, Membrane Fouling Mitigation: Membrane Cleaning, Separation Science and Technology, 45, 7, 858-872. (2010).

80. X. Shi, G. Tal, N.P. Hankins, V. Gitis. Fouling and cleaning of ultrafiltration membranes: A review. Journal of Water Process Engineering, 1, 121-138. (2014).

81. M. Kazemimoghadam, T. Mohammadi, Chemical cleaning of ultrafiltration membranes in the milk industry. Desalination, 204(13), 213-218. (2007).

82. D. Guan, J. Dai, M. Ahmar Siddiqui, G. Chen, Comparison of different chemical cleaning reagents on fouling recovery in a SelfForming dynamic membrane bioreactor (SFDMBR). Separation and Purification Technology, 206, 158-165. (2018).

83. N.M. D'Souza, A.J. Mawson, Membrane cleaning in the dairy industry: a review, Crit Rev Food Sci Nutr, 45, 125-134. (2005).

85. Z. Wang, F. Meng, X. He, Z. Zhou, L.-N. Huang, S. Liang, Optimisation and performance of $4 \mathrm{NaClO}$-assisted maintenance cleaning for fouling control in membrane bioreactors. Water Research, 53, 1-11. (2014).

85. Z. Zhou, F, Meng, H. Lu, T. Li, X. Jia, X. He, Simultaneous alkali supplementation and fouling mitigation in membrane bioreactors by on-line $\mathrm{NaOH}$ backwashing. Journal of Membrane Science, 457, 120-127. (2014).

86. A. Maskooki, S.A. Mortazavi, A. Maskooki, Cleaning of spiral wound ultrafiltration membranes using ultrasound and alkaline solution of EDTA. Desalination, 264(1-2), 63-69 (2010).
87.Carroll, T. (2000). The fouling of microfiltration membranes by NOM after coagulation treatment. Water Research, 34(11), 28612868. (2010).

88. D. Sharma, Treatment of dairy wastewater by electro coagulation using aluminium electrodes and settling, filtration studies. International Journal of Chem. Tech Research, 6(1), 591-599 (2014).

89. V. Mehta, A. Chavan, Physico-chemical treatment of tar-containing wastewater generated from biomass gasification plants. World Academy of Science, Engineering and Technology, 57(9), 161-168 (2009).

90. M. Li, Q. Wen, Z. Chen, Y. Tang, B.Yang, Comparison of ozonation and UV based oxidation as pre-treatment process for ultrafiltration in wastewater reuse: Simultaneous water risks reduction and membrane fouling mitigation. Chemosphere, 125449. (2019).

91. P. Li, X. Cheng, W. Zhou, C. Luo, F. Tan, Z. Ren, D. Wu, Application of sodium percarbonate activated with $\mathrm{Fe}(\mathrm{II})$ for mitigating ultrafiltration membrane fouling by natural organic matter in drinking water treatment. Journal of Cleaner Production, 122228 (2020).

92. X. Chang, T. Lin, W. Chen, H. Xu, H. Tao, Y. Wu, Q. Zhang, S. Yao, A new perspective of membrane fouling control by ultraviolet synergic ferrous iron catalytic persulfate (UV/Fe(II)/PS) as pretreatment prior to ultrafiltration. Science of The Total Environment, 737, 139711 (2020).

93. X.D. Chen, H.W. Yang, W.J. Liu, X.M. Wang, Y.F. Xie, Filterability and structure of the fouling layers of biopolymer coexisting with ferric iron in ultrafiltration membrane. J. Membr. Sci. 495, 81-90. (2015).

94. S. Jiang, Y. Li, B.P. Ladewig, A review of reverse osmosis membrane fouling and control strategies. Science of The Total Environment, 595, 567-583. (2017).

95. F. Liu, N.A. Hashim, Y. Liu, M.R.M. Abed, K. Li, Progress in the production and modification of PVDF membranes. Journal of Membrane Science, 375(1-2), 1-27. (2011).

96. C. Tang, X. Li, The separative capability of $\gamma-\mathrm{Al}_{2} \mathrm{O}_{3}$ porous ceramic membrane modified by ZIF-8, 30(5), 1119-1124. (2013).

97. S. Zhou, A. Xue, Y. Zhang, M. Li, J. Wang, Y. Zhao, W. Xing, Fabrication of temperature-responsive $\mathrm{ZrO}_{2}$ tubular membranes, grafted with poly (N-isopropylacrylamide) brush chains, for protein removal and easy cleaning. Journal of Membrane Science, 450, 351361. (2014).

98. A. Di Mauro, M. Cantarella, G. Nicotra, G. Pellegrino, A. Gulino, M.V. Brundo, G. Impellizzeri, Novel synthesis of ZnO/PMMA nanocomposites for photocatalytic applications. Nature Publishing Group, (October 2016), 1-12. (2017).

99. A.K. Dutta, S.K. Maji, B. Adhikary, G-Fe $\mathrm{O}_{3}$ nanoparticles: An easily recoverable effective photo-catalyst for the degradation of rose bengal and methylene blue dyes in the waste-water treatment plant. Materials Research Bulletin, 49, 28-34. (2014).

100. M. Kurian, D.S. Nair, Journal of Water Process Engineering Heterogeneous Fenton behaviour of nano nickel-zinc ferrite catalysts in the degradation of 4-chlorophenol from water under neutral conditions. Journal of Water Process Engineering, 8, e37-e49 (2015).

101. J.L. Han, X. Xia, M.R. Haider, W.L. Jiang, Y. Tao, M.J. Liu, A.J. Wang, Functional graphene oxide membrane preparation for organics/inorganic salts mixture separation aiming at advanced treatment of refractory wastewater. Science of the Total Environment, 628-629, 261-270. (2018)

102. S. Natarajan, D.S. Lakshmi, V. Thiagarajan, P. Mrudula, N. Chandrasekaran, A. Mukherjee, Antifouling and anti-algal effects of chitosan nanocomposite $\left(\mathrm{TiO}_{2} / \mathrm{Ag}\right)$ and pristine $\left(\mathrm{TiO}_{2}\right.$ and $\left.\mathrm{Ag}\right)$ films on marine microalgae Dunaliella salina. Journal of Environmental Chemical Engineering, 6(6), 6870-6880. (2018).

103. M. Peyravi, M. Jahanshahi, S. Khalili, Fouling of $\mathrm{WO}_{3}$ nanoparticleincorporated PSf membranes in ultrafiltration of land fill leachate and dairy a combined wastewaters : An investigation using model. Chinese Journal of Chemical Engineering, 25(6), 741-751. (2017).

104. D.D. Angelo, S. Filice, $\mathrm{Bi}_{2} \mathrm{O}_{3} / \mathrm{Nexar} \AA$ polymer nanocomposite membranes for azo dyes removal by UV-Vis or Visible light irradiation. Catalysis Today, 321-322(July 2017), 158-163 (2019).

105. I. Kovács, Sz. Kertész, G. Veréb, I.Z. Papp, A. Kukovecz, C. Hodúr, Zs. László, Membrane fouling control using TiO coating during model dairy wastewater filtration. Desalination and Water Treatment, 73(May 2016), 1-7 (2017).

106. L.T. Yogarathinam, A. Gangasalam, A.F. Ismail, S. Arumugam, A. Narayanan, The concentration of whey protein from cheese whey effluent using ultrafiltration by a combination of hydrophilic metal 
oxides and a hydrophobic polymer. Journal of Chemical Technology \& Biotechnology, 93(9), 2576-2591. (2018).

107. K.H. Thebo, X. Qian, Q. Wei, Q. Zhang, H.M. Cheng, W. Ren, Reduced graphene oxide/metal oxide nanoparticles composite membranes for highly efficient molecular separation. Journal of Materials Science and Technology, 34(9), 1481-1486. (2018).

108. A. Bottino, G. Capannelli, A. Comite, Preparation and characterisation of novel porous PVDF-Zr02 composite membranes, 146, 35-40. (2002).

109. L. Yan, Y.S. Li, C.B. Xiang, S. Xianda. Effect of nano-sized $\mathrm{Al}_{2} \mathrm{O}_{3}$ particle addition on PVDF ultrafiltration membrane performance. Journal of Membrane Science, 276(1-2), 162-167. (2006).

110. L. Yu, Z. Xu, H. Shen, H. Yang, Preparation and characterisation of PVDF - $\mathrm{SiO}_{2}$ composite hollow fibre UF membrane by sol-gel method, 337, 257-265. (2009).

111. S. Leong, A. Razmjou, K. Wang, K. Hapgood, X. Zhang, H. Wang, $\mathrm{TiO}_{2}$ based photocatalytic membranes: A review, 472, 167-184. (2014).

112. O. Akhavan, Lasting antibacterial activities of $\mathrm{Ag}-\mathrm{TiO} 2 / \mathrm{Ag} / \mathrm{a}-$ $\mathrm{TiO}$ two nanocomposite thin-film photocatalysts under solar light irradiation. Journal of Colloid and Interface Science, 336(1), 117124. (2009).

113. J. Kumar, A. Bansal. Photocatalysis by Nanoparticles of Titanium Dioxide for Drinking Water Purification: A Conceptual and State-ofArt Review. Materials Science Forum, 764, 130-150. (2013).

114. A. Fujishima, X. Zhang, C.A. Tryk, Surface Science Reports $\mathrm{TiO}_{2}$ photocatalysis and related surface phenomena, 63, 515-582. (2008).

115. S. Lin, M. Thirumavalavan, T. Jiang, J. Lee, Synthesis of $\mathrm{ZnO} / \mathrm{Zn}$ nano photocatalyst using modified polysaccharides for photodegradation of dyes. Carbohydrate Polymers, 105, 1-9. (2014).

116. J. Hong, Y. He, Polyvinylidene fluoride ultrafiltration membrane blended with nano-ZnO particle for photo-catalysis self-cleaning. Desalination, 332(1), 67-75. (2014).

117. S. Liang, K. Xiao, Y. Mo, X. Huang, A novel ZnO nanoparticle blended polyvinylidene fluoride membrane for anti-irreversible fouling. Journal of Membrane Science, 394-395, 184-192. (2012).

118. T.R. McCartney, S. Gharaibeh, R. Shank, 2017. Improved methods for removal of silicate deposits. Heat Exchanger Fouling and Cleaning XII ISBN: 978-0-9984188-0-3; Published online www.heatexchanger-fouling.com

119. D. Zhao, L. Qiu, J. Song, J. Liu, Z. Wang, Y. Zhu, G. Liu, Efficiencies and mechanisms of chemical cleaning agents for nanofiltration membranes used in produced wastewater desalination. Science of The Total Environment, 652, 256-266. (2019).

120. T. Tong, S. Zhao, C. Boo, S.M. Hashmi, M. Elimelech, Relating Silica Scaling in Reverse Osmosis to Membrane Surface Properties. Environmental Science \& Technology, 51(8), 4396-4406. (2017).

121. S. Wang, C. Mu, K. Xiao, X. Zhu, X., Huang, Surface charge regulation of reverse osmosis membrane for anti-silica and organic fouling. Science of The Total Environment, 715, 137013. (2020).

122. Y.-F. Guan, C. Boo, X. Lu, X. Zhou, H.-Q. Yu, M. Elimelech, Surface Functionalization of Reverse Osmosis Membranes with Sulfonic Groups for Simultaneous Mitigation of
Silica Scaling and Organic Fouling. Water Research, 185. 116203. (2020).

123. X. Bao, Q. She, W. Long, Q. Wu, Ammonium ultra-selective membranes for wastewater treatment and nutrient enrichment: Interplay of surface charge and hydrophilicity on fouling propensity and ammonium rejection. Water Research, 190, 116678. (2021).

124. M.H.D.A. Farahani, V. Vatanpour, A comprehensive study on the performance and antifouling enhancement of the PVDF mixed matrix membranes by embedding different nanoparticles: Clay, functionalized carbon nanotube, $\mathrm{SiO}_{2}$ and $\mathrm{TiO}_{2}$. Separation and Purification Technology, 197, 372-381(2018).

125. H. Susanto, R. Desiriani, A. Adi, D. Hermita, Incorporation of Nanoparticles as Antifouling Agents into PES UF Membrane. Materials Today: Proceedings, 13, 217-223. (2019).

126. M.I. Maldonado, J. Blanco, W. Gernjak, S. Malato, P. Ferna, Decontamination and disinfection of water by solar photocatalysis: recent overview and trends, 147, 1-59. (2009).

127. A. Trapalis, N. Todorova, T. Giannakopoulou, N. Boukos, T. Speliotis, D. Dimotikali, J. Yu, $\mathrm{TiO}_{2} /$ Graphene Composite Photocatalysts for NOx Removal: A Comparison of Surfactantstabilized Graphene and Reduced Graphene Oxide. Applied Catalysis B: Environmental, 180, 637-647. (2016).

128. X. Zheng, Z. Shen, L. Shi, R. Cheng, Photocatalytic Membrane Reactors ( PMRs ) in Water Treatment: Configurations and Influencing Factors, Catalysts, 7, 224-254 (2017).

129. Z. Yue, A. Liu, C. Zhang, J. Huang, M. Zhu, Y. Du, P. Yang, Noblemetal-free hetero-structural $\mathrm{CdS} / \mathrm{Nb}_{2} \mathrm{O}_{5} / \mathrm{N}$ doped-graphene ternary photocatalytic system as visible-light-driven photocatalyst for hydrogen evolution. Applied Catalysis B, Environmental, 201, 202210 (2017).

130. T. Das, X. Rocquefelte, R. Laskowski, L. Lajaunie, P. Blaha, Investigation of the Optical and Excitonic Properties of the Visible Light-Driven Photocatalytic $\mathrm{BiVO}_{4}$ Material, Chem. Mater. 2017, 29, 8, 3380-3386. (2017).

131. S.F. Yang, C.G. Niu, D.W. Huang, H. Zhang, C. Liang, G.M. Zeng, $\mathrm{SrTiO}_{3}$ nanocubes decorated with $\mathrm{Ag} / \mathrm{AgCl}$ nanoparticles as photocatalysts with enhanced visible-light photocatalytic activity towards the degradation of dyes, phenol and bisphenol $\mathrm{A}$. Environmental Science: Nano, 4(3), 585-595. (2017).

132. S. Nezar, Y. Cherifi, A. Barras, A. Added, E. Dogheche, N. Saoula, N.A. Laoufi, P. Roussel, S. Szurenits, R. Boukherroub, Efficient reduction of $\mathrm{Cr}(\mathrm{VI})$ under visible light irradiation using $\mathrm{CuS}$ nanostructures. Arabian Journal of Chemistry 12(2), 215-224. (2019).

133. G. Žerjav, P. Djinović, A.Pintar, $\mathrm{TiO}_{2}-\mathrm{Bi}_{2} \mathrm{O}_{3} /(\mathrm{BiO})_{2} \mathrm{CO}_{3}$-reduced graphene oxide composite as an effective visible light photocatalyst for degradation of aqueous bisphenol A solutions. Catalysis Today, 315, 237-246 (2018).

134. A.B. Lavand, Y.S. Malghe, Synthesis, characterisation and visible light photocatalytic activity of carbon and iron modified $\mathrm{ZnO}$. Journal of King Saud University - Science, 30(1), 65-74 (2018). 